\title{
Article
}

\section{Simultaneous culture and biomachining of copper in MAC medium: A comparison between Acidithiobacillus ferrooxidans and Sulfobacillus thermosulfidooxidans}

\author{
Estibaliz Diaz-Tena, Gorka Gallastegui, Marcela Hipperdinger, Edgardo Donati, \\ Naiara Rojo, Arrate Santaolalla, Martín Ramírez, Astrid Barona, and Ana Elias \\ ACS Sustainable Chem. Eng., Just Accepted Manuscript • DOI: 10.1021/ \\ acssuschemeng.8b04348 Publication Date (Web): 22 Oct 2018
}

Downloaded from http://pubs.acs.org on October 31, 2018

\section{Just Accepted}

"Just Accepted" manuscripts have been peer-reviewed and accepted for publication. They are posted online prior to technical editing, formatting for publication and author proofing. The American Chemical Society provides "Just Accepted" as a service to the research community to expedite the dissemination of scientific material as soon as possible after acceptance. "Just Accepted" manuscripts appear in full in PDF format accompanied by an HTML abstract. "Just Accepted" manuscripts have been fully peer reviewed, but should not be considered the official version of record. They are citable by the Digital Object Identifier (DOI®). "Just Accepted" is an optional service offered to authors. Therefore, the "Just Accepted" Web site may not include all articles that will be published in the journal. After a manuscript is technically edited and formatted, it will be removed from the "Just Accepted" Web site and published as an ASAP article. Note that technical editing may introduce minor changes to the manuscript text and/or graphics which could affect content, and all legal disclaimers and ethical guidelines that apply to the journal pertain. ACS cannot be held responsible for errors or consequences arising from the use of information contained in these "Just Accepted" manuscripts. 


\title{
Simultaneous culture and biomachining of copper in MAC medium: A comparison between Acidithiobacillus ferrooxidans and Sulfobacillus thermosulfidooxidans
}

\author{
E. Díaz-Tena ${ }^{a, b^{*}}{ }^{\text {, G. Gallastegui }}{ }^{c}$, M. Hipperdinger ${ }^{\text {b }}$, E.R Donati ${ }^{\text {b }}$, N. Rojo ${ }^{c}$, A. Santaolalla ${ }^{c}$, M. Ramirez $^{d}$, \\ A. Barona ${ }^{a}$, A. Elías ${ }^{\text {a }}$ \\ ${ }^{a}$ Department of Chemical Engineering and Environment. Faculty of Engineering of Bilbao, University of \\ the Basque Country (UPV/EHU). Alameda Urquijo s/n, 48013, Bilbao, Spain \\ ${ }^{b}$ CINDEFI (CCT La Plata-CONICET, U.N.LP.). Faculty of Science, National University of La Plata, 47 and 115, \\ 1900, La Plata, Argentina \\ 'Department of Chemical and Environmental Engineering, Faculty of Engineering Vitoria-Gasteiz, \\ University of the Basque Country (UPV/EHU), Nieves Cano 12, 01006 Vitoria-Gasteiz, Spain \\ ${ }^{d}$ Department of Chemical Engineering and Food Technologies. Faculty of Sciences, University of Cadiz, \\ Puerto Real, 11510 Cádiz, Spain
}

\section{*Corresponding author:}

\section{E. Díaz-Tena}

Department of Chemical Engineering and Environment - University of the Basque Country (UPV/EHU) Faculty of Engineering of Bilbao. Alameda de Urquijo s/n. 48013 Bilbao, Spain

Tf: +34946014087

Email: estibaliz.diaz@ehu.eus

\section{ABSTRACT}

Biomachining will not be considered as a full-scale manufacturing technology until a stable, controlled and continuous metal removal rate (MRR) is achieved. In this research work, a novel strategy that could promote its industrial implementation, namely simultaneous bacterial growth and machining of copper contained in oxygen-free copper (OFC) workpieces, was investigated. This proposal has the major advantage of being a single-stage process, thereby reducing total operating times and becoming more economical in comparison with conventional biomachining (downtime due to bacterial growth would disappear). The study was carried out using mesophilic (Acidithiobacillus ferrooxidans) and thermophilic (Sulfobacillus thermosulfidooxidans) extremophile bacteria in order to prevent the progressive decrease in the amount of metal removed per unit time. A constant MRR of $43 \mathrm{mg} \mathrm{h}^{-1}$ was achieved with $A$. ferrooxidans in the simultaneous process. Despite the accomplishment of a constant MRR, this value is lower than the maximum MRR obtained in conventional biomachining $\left(109 \mathrm{mg} \mathrm{h}^{-1}\right)$, probably due to the inability of ferric ions to come into contact with the metallic surface. With regard to the culture period in MAC medium, S. thermosulfidooxidans showed a slower growth rate $\left(0.11 \mathrm{~h}^{-1}\right)$ and lower ferrous ion oxidation level $\left(0.12 \mathrm{~g} \mathrm{Fe}^{2+} \mathrm{L}^{-1} \mathrm{~h}^{-1}\right)$ than $A$. ferrooxidans $\left(0.17 \mathrm{~h}^{-1}\right.$ and $0.22 \mathrm{~g} \mathrm{Fe}^{2+} \mathrm{L}^{-1} \mathrm{~h}^{-1}$, respectively) under optimal $\mathrm{pH}(1.5)$ and $\mathrm{Fe}^{2+}$ concentration $\left(6 \mathrm{~g} \mathrm{~L}^{-1}\right)$ conditions.

KEYWORDS: biomachining, bioleaching, copper, MAC medium, A. ferrooxidans, S. thermosulfidooxidans 


\section{INTRODUCTION}

Copper has been identified as a key metal for industrial and social progress. Indeed, both copper and its many alloys (e.g., oxygen-free copper (OFC) pieces) have become strategic materials due to their economic and environmental benefits ${ }^{1}$. It is estimated that two-thirds of the 550 million tonnes of copper produced since 1900 are still in productive use ${ }^{2}$. Its excellent properties, such as mechanical strength, conductivity, corrosion resistance, machinability, ductility and recyclability, make copper ideal for use in a large number of products and a wide range of applications, including electronics, communication, electricity and transport. For instance, a typical medium-sized car may contain up to $22.5 \mathrm{~kg}$ of this metal, and new generation aircraft and trains between 2 and 4 tons ${ }^{1}$.

With regard to OFC microfabrication, physicochemical methods, such as milling, turning, drilling, laser, electrical discharge machining and chemical machining, have traditionally been applied. However, the high fabrication rates achieved have masked the drawbacks associated with these processes, namely high production costs, thermal and/or structural damage, and the application of harmful compounds for both employees' health and the environment. As a result, and given the environmental impact caused by the traditional manufacturing sector, concepts such as ecological and sustainable production are gaining more and more importance, and industries are increasingly being forced to retrain their processes (either by integrating new processes or transforming existing ones), thereby moving towards a greener manufacturing technology. According to Pusavec et al. $^{3}$, any environmentally sustainable process is based on four basic principles: (1) process cost depletion (including energy consumption and manufacturing process costs), (2) generated waste reduction and waste-treatment upgrading, (3) occupational health progress, and (4) a decrease in environmental impact.

Numerous approaches based on traditional manufacturing processes that improve progress towards socalled "green manufacturing" have arisen recently. These new processes are more efficient and ecofriendly than existing ones. Although their application to date has been limited to a laboratory scale, biomachining, which is defined as a process based on microbiological activity to form microstructures on a metal workpiece by metal removal (or dissolution) using microorganisms, is one of the possible alternatives for OFC microfabrication purposes ${ }^{4}$. Biomachining is characterised by machining components with minimum heat or residual stress and without damaging the metallurgical properties of the workpieces. Microorganisms responsible for the metal processing are not only commercially available, but also can be cultured and be readily available at any moment. In addition, energy consumption is low, thus resulting in a subsequent cost saving in the manufacturing of high quality pieces $^{5,6}$.

Two main mechanisms (direct and indirect pathways) have been postulated to explain metal bioetching $^{7}$. Regarding the direct mechanism, bacterial adhesion on metal surface allows the enzyme activity to be responsible for metal oxidation and dissolution ${ }^{5}$. Nevertheless, according to the literature, this process is not the priority pathway for zero-valence copper $\left(\mathrm{Cu}^{0}\right)$ biooxidation ${ }^{6,8}$. Xenofontos et al. ${ }^{8}$ observed that even if the effect of microorganisms on copper foil surface roughness was significant, the direct mechanism contributed only $5 \%$ to the total biomachining process.

Copper biomachining via indirect mechanism typically involves two consecutive stages ${ }^{9}$. Initially, chemolithotrophic and acidophilic bacteria are grown using the energy generated by the oxidation of ferrous ions into ferric ions (Reaction 1), and in a second step, the biogenic ferric ion causes the dissolution of copper metal present in the bacterial medium (Reaction 2).

$2 \mathrm{Fe}^{2+}+1 / 2 \mathrm{O}_{2}+2 \mathrm{H}^{+} \rightarrow 2 \mathrm{Fe}^{3+}+\mathrm{H}_{2} \mathrm{O} \quad$ (Reaction 1) 
$\mathrm{Cu}^{0}+2 \mathrm{Fe}^{3+} \rightarrow \mathrm{Cu}^{2+}+2 \mathrm{Fe}^{2+}$

(Reaction 2)

Ideally, a closed cycle should be formed by joint interaction between the biological (Reaction 1) and chemical (Reaction 2) reactions. However, the relatively low biological metabolism in comparison with the fast chemical copper dissolution rate results in a depletion of the $\mathrm{Fe}^{3+}$ concentration in the liquid medium (Figure 1a), thereby decreasing the metal removal rate (MRR) over time ${ }^{10}$. In previous studies ${ }^{4}$, the MRR was optimized by means of regeneration periods between successive stages of biomachining (Figure 1b). Thus, during the chemical solution bioregeneration, the piece of metal was submerged in a second bioreactor in order to continue the leaching process at the highest possible MRR ${ }^{11}$.

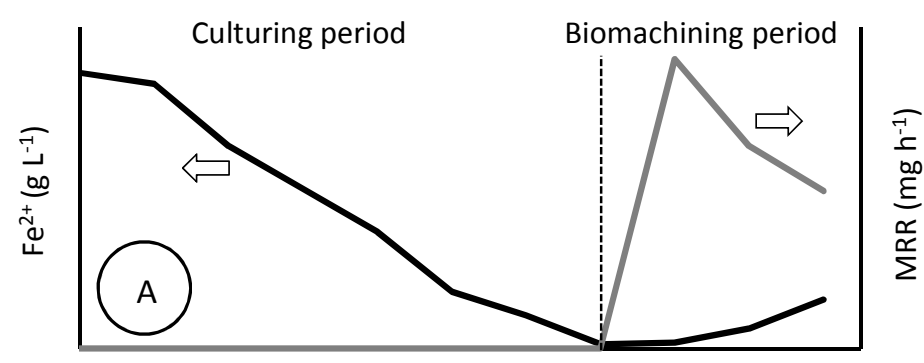

Time (h)
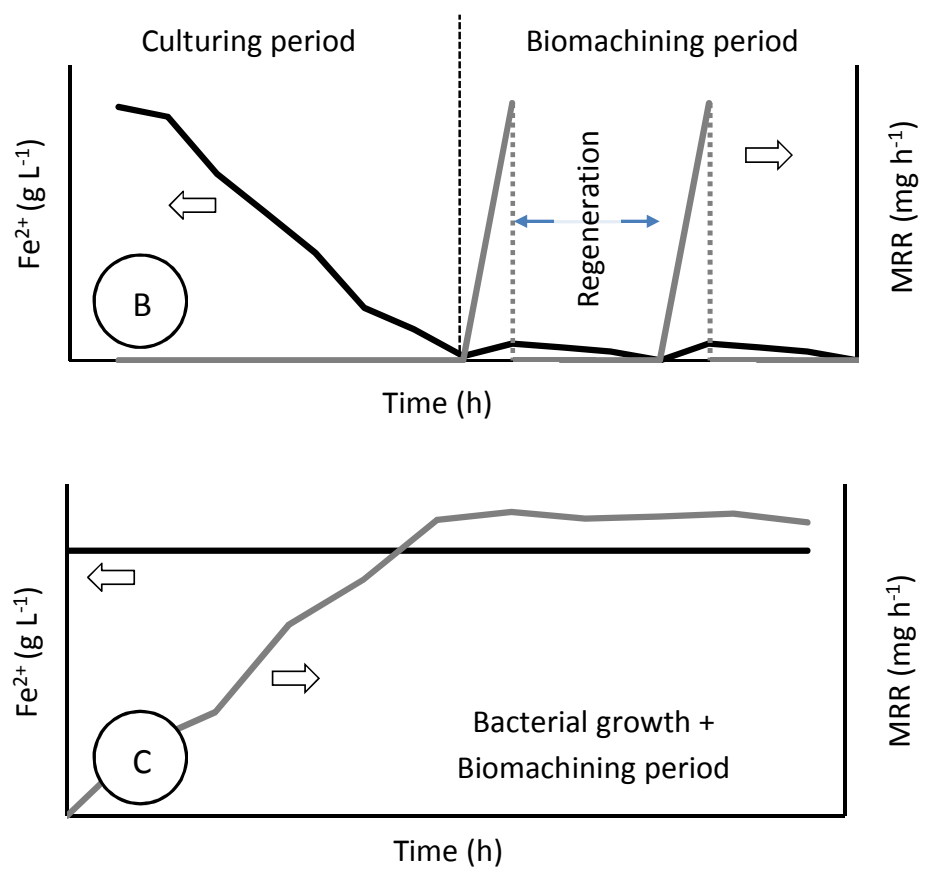

Figure 1. Evolution of $\mathrm{Fe}^{2+}$ concentration (black line) and metal removal rate (grey line) for a conventional biomachining process $(A)$, an alternative biomachining process including regeneration periods (B), and a simultaneous bacterial growth and biomachining process (C).

The work described herein explores the possibility of carrying out the bacterial growth and machining stages simultaneously in order to provide a continuous, stable and sustainable biomachining process. The total operating time would be reduced in comparison with conventional biomachining as the growth period (Reaction 1) would act as a producing stage that occurs alongside copper dissolution (Reaction 2). In addition, the energy source for bacterial growth (i.e., $\mathrm{Fe}^{2+}$ ) would be readily available since the ferric ions generated would be rapidly reduced upon interaction with elemental copper $\left(\mathrm{Cu}^{0}\right)$ (Reaction 2). Such an alternative approach could provide an endless energy source for the microorganisms, thus 
meaning that they would be immersed in a growth stage at a suitable activity level for machining purposes (Figure 1c).

The most commonly used bacterium in biomachining is the autotrophic, acidophilic and mesophilic bacterium Acidithiobacillus ferrooxidans (A. ferrooxidans). Thermophilic bacteria typically employed in the bioleaching of sulfide ores and environmental detoxification of heavy metals have not yet been investigated as possible agents for increasing the biomachining rate. As such, experimental data regarding the growth and machining capacity of Sulfobacillus thermosulfidooxidans (S. thermosulfidooxidans) were also compared with those for $A$. ferrooxidans in this study.

\section{EXPERIMENTAL SECTION}

\section{Preparation of copper samples}

OFC workpieces with a minimum purity of $99.99 \%$ and a size of $10 \times 15 \times 2 \mathrm{~mm}$ were manufactured in the Department of Mechanical Engineering of the University of the Basque Country (UPV/EHU) using an 800-grit abrasive disk wheel (Petrographic cleaner LS1, REMET, Italy). Each workpiece had a hole ( $2 \mathrm{~mm}$ in diameter and $2 \mathrm{~mm}$ thick) to allow complete immersion in the active medium when performing the tests (SI Figure S1). Prior to immersion in MAC medium, the OFC blocks were rinsed with deionized water and ethanol $\left(96 \% \vee v^{-1}\right)$ and then heated to remove surface moisture.

\section{Microorganisms and culture media}

A. ferrooxidans DSM-14882 was kindly provided by the Department of Chemical Engineering and Food Technology of the University of Cádiz (UCA) and S. thermosulfidooxidans was obtained from Copahue geothermal ponds (Neuquen, Argentina).

The mineral medium ( $\mathrm{MAC}^{12}$ ) composition $\left(\mathrm{g} \mathrm{L}^{-1}\right)$ was: 1$) 1 \mathrm{~L}$ basalt solution, comprising: $0.132\left(\mathrm{NH}_{4}\right)_{2} \mathrm{SO}_{4}$, $0.031 \mathrm{MgSO}_{4} \cdot 7 \mathrm{H}_{2} \mathrm{O}, 0.147 \mathrm{CaCl}_{2} \cdot 2 \mathrm{H}_{2} \mathrm{O}, 0.022 \mathrm{~K}_{2} \mathrm{HPO}_{4}$; 2) $1 \mathrm{~mL}$ trace elements, comprising: 0.099 $\mathrm{MgCl}_{2} \cdot 4 \mathrm{H}_{2} \mathrm{O}, 0.068 \mathrm{ZnCl}_{2}, 0.101 \mathrm{CoCl}_{2} \cdot 6 \mathrm{H}_{2} \mathrm{O}, 0.031 \mathrm{H}_{3} \mathrm{BO}_{3}, 0.012 \mathrm{Na}_{2} \mathrm{MoO}_{4} \cdot 2 \mathrm{H}_{2} \mathrm{O}, 0.085 \mathrm{CuCl}_{2} \cdot 2 \mathrm{H}_{2} \mathrm{O}$. $\mathrm{FeSO}_{4} \cdot 7 \mathrm{H}_{2} \mathrm{O}$ was added in different quantities depending on the final $\mathrm{Fe}^{2+}$ concentration required.

\section{Study of the effect of initial $\mathrm{pH}$ and $\mathrm{Fe}^{2+}$ concentration on $\mathrm{A}$. ferrooxidans and $S$. thermosulfidooxidans kinetics}

Both bacteria were cultured in $250 \mathrm{~mL}$ conical flasks containing $150 \mathrm{~mL}$ of MAC medium supplemented with $\mathrm{FeSO}_{4} \cdot 7 \mathrm{H}_{2} \mathrm{O}$, which served as bacterial energy source. Bacteria were incubated under agitation conditions (180 rpm) (ShakerPro 6004, Vicking, Argentina) at $30^{\circ} \mathrm{C}$ and $45^{\circ} \mathrm{C}$ for $A$. ferrooxidans and $S$. thermosulfidooxidans, respectively.

As the $\mathrm{pH}$ was not adjusted during the culture period, this stage was concluded when complete oxidation of $\mathrm{Fe}^{2+}$ to $\mathrm{Fe}^{3+}$ was achieved (less than $1 \%$ of the initial $\mathrm{Fe}^{2+}$ concentration), which indicated that bacterial growth was satisfactory, or jarosite precipitation due to progressive basification was observed ${ }^{4}$.

To analyse the effect of $\mathrm{pH}$ and $\mathrm{Fe}^{2+}$ concentration, two $\mathrm{pH}$ values (1.5 and 2.0) and three $\mathrm{Fe}^{2+}$ concentrations $\left(3,6\right.$ and $\left.9 \mathrm{~g} \mathrm{Fe}^{2+} \mathrm{L}^{-1}\right)$ were tested. $\mathrm{pH}$ tests below 1.5 were not performed since a marked reduction in $A$. ferrooxidans viability has already been observed by Gomez and Cantero ${ }^{13}$ when working at a pH of 1.25. With regard to $S$. thermosulfidooxidans, prior research indicated that ferrous ion oxidation rates were similar between $\mathrm{pH} 1.4-2.0$, with an optimum $\mathrm{pH}$ of $1.7^{14}$. Deionized water was added during the experiments to compensate water losses due to evaporation. Blank tests following the 
same procedure were performed without bacteria to verify the oxidation capacity $\left(\mathrm{Fe}^{2+} \rightarrow \mathrm{Fe}^{3+}\right.$ ) of dissolved oxygen. An additional test was performed for $S$. thermosulfidooxidans at $\mathrm{pH} 1.5$ and $6 \mathrm{~g} \mathrm{Fe}^{2+} \mathrm{L}^{-}$ ${ }^{1}$ in the presence of $300 \mu \mathrm{L}$ of yeast extract $\left(10 \% \mathrm{w} \mathrm{v}^{-1}\right)$. Each experiment was performed in duplicate and the mean results were used.

\section{Biomachining process}

\section{Conventional biomachining process}

Biomachining tests were carried out by suspending pre-weighed OFC copper blocks (Sartorius Practum 124-1S analytical Balance, Spain) in $250 \mathrm{~mL}$ conical flasks containing the aforementioned culture media (A. ferrooxidans or S. thermosulfidooxidans, both cultured up to stationary phase ${ }^{15}$ ) under the optimal conditions based upon the results obtained in "Parameters affecting the culture period" section ( $\mathrm{pH}$ of 1.5 and $6 \mathrm{~g} \mathrm{Fe}^{2+} \mathrm{L}^{-1}$ ) (Table 1). The influence of workpiece dimensions ${ }^{16}$ was avoided by selecting analogous pieces in terms of both weight and total surface area. A pH threshold value of 1.8 was maintained in all experiments by addition of sulfuric acid $\left(25 \% v^{-1}\right)^{4}$.

\section{Biomachining during the culture period}

Tests to analyse the effect of conducting bacterial culture (A. ferrooxidans or $S$. thermosulfidooxidans) and biomachining simultaneously were performed in four different solutions, as shown in Table 1. In this case, copper bioleaching was considered to be complete either when dissolutions presented jarosite formation (in the samples with no $\mathrm{pH}$ control) or the MRR ceased to increase over time. Irrespective of the fact that copper OFC samples were placed within the flasks together with the uncultured inoculum (SI Figure S1), the same conditions as those mentioned in the previous section were applied in these experiments.

Table 1. Experimental conditions regarding conventional and alternative biomachining procedures.

\begin{tabular}{llllll}
\hline Experiment & Bacteria & Initial $\mathrm{pH}$ & Temperature $\left({ }^{\circ} \mathrm{C}\right)$ & {$\left[\mathrm{Fe}^{2+}\right]\left(\mathrm{g} \mathrm{L}^{-1}\right)$} & $\mathrm{pH}$ control \\
\hline $\begin{array}{l}\text { Conventional } \\
\text { biomachining }\end{array}$ & A. ferrooxidans & 1.5 & 30 & 6 & Yes \\
\hline & S. thermosulfidooxidans & 1.5 & 45 & 6 & Yes \\
\hline \multirow{2}{*}{$\begin{array}{l}\text { Simultaneous culture } \\
\text { and biomachining }\end{array}$} & A. ferrooxidans & 1.5 & 30 & 6 & No \\
& S. thermosulfidooxidans & 1.5 & 45 & 6 & Yes \\
& S. thermosulfidooxidans & 1.5 & 45 & 6 & No \\
\hline
\end{tabular}

The metal samples tested in the latter two sections were removed from the solution at user-defined intervals, rinsed with deionized water and ethanol $\left(96 \% v^{-1}\right)$, dried, weighed, and then reintroduced into the liquid samples. Each experiment was performed in duplicate and the mean results were used. The copper removal rate (MRR) achieved was calculated as follows ${ }^{9}$ :

$\operatorname{MRR}\left(\mathrm{mg} \mathrm{h}^{-1}\right)=\frac{\text { Weight loss }(\mathrm{mg})}{\text { Time }(\mathrm{h})}$

$\mathrm{Cu}^{2+}, \mathrm{Fe}^{2+}, \mathrm{Fe}^{3+}$ and total Fe determination

$\mathrm{Fe}^{2+}$ concentration was quantified using the $o$-phenanthroline method with a NanoColor ${ }^{\circledR}$ UV/VIS spectrophotometer (Macherey-Nagel GmbH \& Co., KG, Germany) ${ }^{17} . \mathrm{Cu}^{2+}$ and total Fe concentrations 
were determined for filtered samples by atomic absorption spectrophotometry (AA-6650, Shimadzu, France). The $\mathrm{Fe}^{3+}$ concentration was calculated as the difference between total and ferrous ion. Samples were rapidly filtered $\left(0.45 \mu \mathrm{m}\right.$ FilterLab membrane filter) prior to $\mathrm{Fe}^{2+}$ and $\mathrm{Fe}^{3+}$ determination to accurately disrupt the activity of remaining bacteria present in the media ${ }^{4}$.

\section{Other analyses}

The total cell number was calculated using a counting chamber (Improved Neubauer counting chamber, Zuzi, Spain) in conjunction with a phase-contrast microscope (Labophot, Nikon, USA). Additionally, cell densities were compared using the $4^{\prime}, 6^{\prime}$-diamidino-2-phenylindole (DAPI) stain technique ${ }^{18}$. Supporting data, namely $\mathrm{pH}$ (GLP 21+ pH-meter equipped with a sensION+5014T glass combination $\mathrm{pH}$ electrode, Crison, Spain) and redox potential (Orion 9778BNWP Sure-Flow ${ }^{\circledR}$ electrode with epoxy body (combination of a platinum redox and a silver/silver chloride reference electrode in one body $(\mathrm{Ag} / \mathrm{AgCl}$, $4 \mathrm{M} \mathrm{KCl})$ ) connected to a Thermo-Orion 920A+ meter, ThermoFisher Scientific, Germany), were measured to provide additional information regarding the stage of the process. All potentials in this paper are given with respect to the reference electrode (+220 $\mathrm{mV}$ vs. $\mathrm{Ag} / \mathrm{AgCl})$.

\section{RESULTS AND DISCUSSION}

\section{Effect of initial $\mathrm{pH}$ and $\mathrm{Fe}^{2+}$ concentration on A. ferrooxidans and S. thermosulfidooxidans kinetics}

\section{A. ferrooxidans}

An optimal culture medium formulation and suitable growth conditions are essential in any biological process in which bacteria are involved in order to attain their maximal growth rate and replication. For A. ferrooxidans culture in MAC medium, samples with an initial $\mathrm{pH}$ of 2.0 presented a slightly lower growth rate in comparison with samples with an initial $\mathrm{pH}$ of 1.5 . A difference of approximately $10 \%$ in the bacterial concentration increase was observed when samples with a Fe ${ }^{2+}$ concentration of $3 \mathrm{~g} \mathrm{~L}^{-1}$ but different $\mathrm{pH}$ values (1.5 or 2.0) were compared (Figure 2). For the sake of clarity, samples with an initial $\mathrm{pH}$ of 2.0 and the highest $\mathrm{Fe}^{2+}$ concentrations $\left(6 \mathrm{~g} \mathrm{~L}^{-1}\right.$ and $\left.9 \mathrm{~g} \mathrm{~L}^{-1}\right)$ were not included in Figure 2 . In these latter two cases, jarosite precipitation (SI Figure S2) was evident when the $\mathrm{pH}$ rose above 2.3, which was in accordance with Nazari et $\mathrm{al}^{19}$. As expected, a higher bacterial density was achieved in those samples with a higher iron concentration, which was visually corroborated by means of DAPI analysis (SI Figure S3).

Biological oxidation of $\mathrm{Fe}^{2+}$ to $\mathrm{Fe}^{3+}$ in samples grown at a $\mathrm{pH}$ of 1.5 resulted in an average increase in the $\mathrm{pH}$ value of 0.5 as a result of the consumption of hydrogen ions. Proton depletion was similar irrespective of the $\mathrm{Fe}^{2+}$ content (Figure 2). The time required by the inoculum to accomplish $\mathrm{Fe}^{2+}$ oxidation and achieve the maximum redox potential (590-630 $\mathrm{mV}$ vs. $\mathrm{Ag} / \mathrm{AgCl}$ ) essentially depended on the amount of ferrous ion in the media (SI Figure S4). In all cases, the culture period was completed within $38 \mathrm{~h}$. Blank tests (abiotic tests developed to observe ferrous ion oxidation associated with dissolved oxygen) showed a negligible $\mathrm{Fe}^{2+}$ depletion in samples at $\mathrm{pH} 1.5$ or $\mathrm{pH} 2.0$. For the same culture period $(24 \mathrm{~h})$, minor increases $(6-17 \mathrm{mV}(\uparrow 2-5 \%))$ in the redox potential associated with the conversion of $\mathrm{Fe}^{2+}$ into $\mathrm{Fe}^{3+}$ were measured, which confirmed the applicability of the redox potential as a rapid measurement for gaining information about the status of the biomachining process ${ }^{4}$. 
2

3

4

5

6

7

8

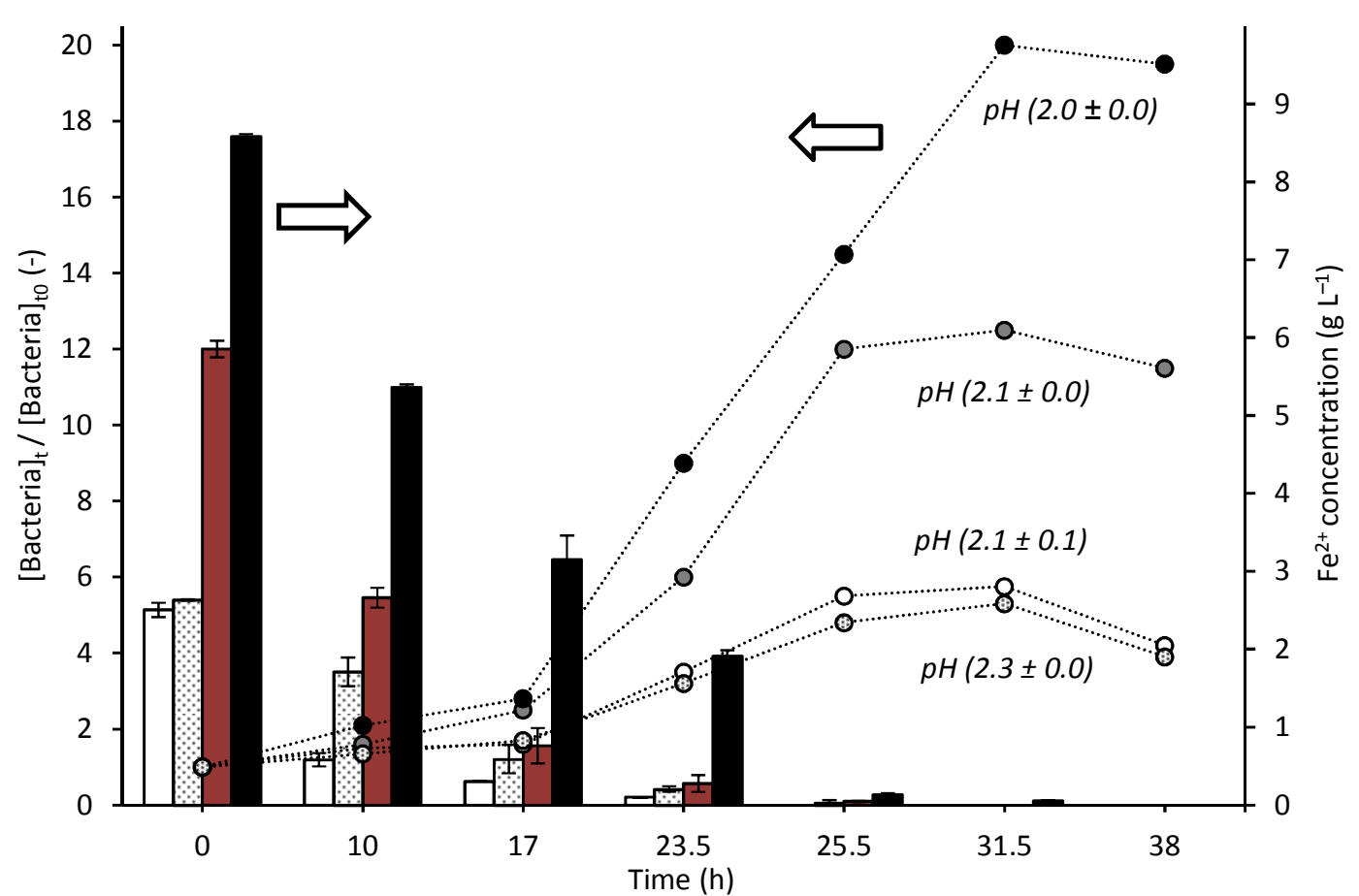

Figure 2. Evolution of $\mathrm{Fe}^{2+}$ (columns) and bacteria (circles) concentration during the culture of $A$. ferrooxidans in MAC medium for the three $\mathrm{Fe}^{2+}$ concentrations: $3 \mathrm{~g} \mathrm{Fe}^{2+} \mathrm{L}^{-1}(\mathrm{pH} 1.5$ (white) and $\mathrm{pH} 2.0$ (dotted)), $6 \mathrm{~g} \mathrm{Fe}^{2+} \mathrm{L}^{-1}$ and $\mathrm{pH} 1.5$ (grey), and $9 \mathrm{~g} \mathrm{Fe}^{2+} \mathrm{L}^{-1}$ and $\mathrm{pH} 1.5$ (black). Error bars represent one standard deviation of the duplicates.

Taking into account that the variables with the highest influence on $A$. ferroxidans metabolism are ferrous and ferric ion concentration, $\mathrm{pH}$, temperature, dissolved oxygen concentration, carbon dioxide concentration and inert solids ${ }^{13}$, the effect of $\mathrm{pH}$ and $\mathrm{Fe}^{2+}$ concentration on the $\mathrm{Fe}^{2+}$ oxidation rate $\left(\mathrm{Fe}^{2+}\right)$, specific bacteria growth rate $(\mu)$ and specific substrate consumption $\left(\mathrm{q}_{\mathrm{s}}\right)$ were addressed in this section in order to establish the optimal conditions for $A$. ferroxidans culture in MAC medium (Table 2). The $\mu$ and $v_{\mathrm{Fe}^{2+}}$ rates were calculated during the bacterial exponential growth phase, as defined by Blanch and $\mathrm{Clark}^{20} . \mathrm{q}_{\mathrm{s}}$ was obtained as the ratio between bacterial growth rate and cell yield, which is defined as the amount of cells produced per unit amount of substrate consumed ${ }^{20}$.

Previous studies have demonstrated that the rate of $\mathrm{Fe}^{2+}$ bio-oxidation by $A$. ferrooxidans is highest when the dissolved oxygen level is maintained above $20 \%$ of the saturation value ${ }^{21,22}$. Given the absence of suspended and finely ground inert solids in the Erlenmeyer flasks and that the dissolved oxygen concentration far outweighed the minimum value established in the literature $\left(\sim 1.5-2 \mathrm{mg} \mathrm{L}^{-1}\right)$ throughout the experiments carried out, the influence of dissolved oxygen concentration and inert solids presence was discarded in this study. 
Table 2. $\mathrm{Fe}^{2+}$ oxidation rate $\left(\mathrm{V}_{\mathrm{Fe}^{2+}}\right)$, specific bacteria growth rate $(\mu)$ and specific substrate consumption $\left(\mathrm{q}_{\mathrm{s}}\right)$ for $A$. ferrooxidans and $\mathrm{S}$. thermosulfidooxidans cultured in MAC medium.

\begin{tabular}{|c|c|c|c|c|c|c|c|c|}
\hline Bacteria & Strain & Medium & {$\left[\mathrm{Fe}^{2+}\right]_{\text {initial }}\left(\mathrm{g} \mathrm{L}^{-1}\right)$} & $\mathrm{pH}$ & $\mathrm{v}_{\mathrm{Fe}^{2+}}\left(\mathrm{g} \mathrm{Fe}^{2+} \mathrm{L}^{-1} h^{-1}\right)$ & $\mu\left(h^{-1}\right)$ & $q_{s}\left(m F^{2+}\right.$ Mcell $\left.^{-1} h^{-1}\right)$ & Reference \\
\hline \multirow{9}{*}{ A. ferrooxidans } & DSM 14882 & MAC & 3 & 1.5 & 0.096 & 0.14 & 0.008 & This study \\
\hline & DSM 14882 & MAC & $3^{(\mathrm{a})}$ & 2.0 & 0.089 & 0.12 & 0.007 & This study \\
\hline & DSM 14882 & MAC & 6 & 1.5 & 0.217 & 0.17 & 0.009 & This study \\
\hline & DSM 14882 & MAC & 9 & 1.5 & 0.248 & 0.14 & 0.007 & This study \\
\hline & ATCC 19859 & $9 K$ & $2-3$ & 1.9 & - & $0.12-0.13$ & - & (23) \\
\hline & $--^{(b)}$ & $9 K^{(c)}$ & 2 & 1.8 & $0.06^{(\mathrm{d})}$ & 0.14 & - & (24) \\
\hline & ATTC 13728 & $9 K^{(c)}$ & 3 & - & - & 0.145 & 0.0037 & (25) \\
\hline & $\operatorname{TfH}^{(\mathrm{e})}$ & $9 \mathrm{~K}$ & 9 & 1.5 & - & 0.080 & 0.0052 & (26) \\
\hline & SIMA 8621 & $9 \mathrm{~K}$ & 9 & 2.2 & & 0.183 & 0.0036 & (27) \\
\hline \multirow{5}{*}{ S. thermosulfidooxidans } & $-{ }^{(f)}$ & MAC & 6 & 1.5 & 0.120 & 0.11 & 0.039 & This study \\
\hline & DSM $9293^{\top}$ & Watling $^{(\mathrm{g})}$ & 10 & $1.6-1.8$ & $0.12^{(\mathrm{d})}$ & & & (14) \\
\hline & DSM 9293 & Norris & 2.5 & 1.5 & 0.179 & - & - & (28) \\
\hline & DSM 9293 & Norris & 5 & 1.5 & 0.480 & 0.22 & 0.028 & (29) \\
\hline & DSM 9293 & Norris & 20 & 1.5 & 0.564 & 0.25 & 0.064 & (29) \\
\hline \multicolumn{9}{|c|}{$\begin{array}{l}\text { (a) Samples with an initial } \mathrm{pH} \text { of } 2.0 \text { and the highest Fe }{ }^{2+} \text { concentrations }\left(6 \mathrm{~g} \mathrm{~L}^{-1} \text { and } 9 \mathrm{~g} \mathrm{~L}^{-1}\right) \text { were not included due to jarosite formation, a physical barrier which } \\
\text { prevents effective diffusion of the reagents and products. } \\
\text { (b) } \text { Isolated from the Rio Tinto mine in Huelva (Spain) }\end{array}$} \\
\hline $\begin{array}{l}\text { (c) The inorganic salt med } \\
\mathrm{FeSO}_{4} \text { content, which wa } \\
\text { (d) Graphically inferred. } \\
\text { (e) Isolated from Hutti Go } \\
\text { (f) Isolated from Copahue } \\
\text { (g) Basal salt medium was }\end{array}$ & $\begin{array}{l}\text { n employed b } \\
\text { nodified in ord } \\
\text { mines (India) } \\
\text { othermal pon }\end{array}$ & $\begin{array}{l}\text { Gomez \& } \mathrm{C} \\
\text { r to achieve } \\
\text { S (Argentina }\end{array}$ & $\begin{array}{l}\text { tero } \\
\text { n initial } \mathrm{Fe}^{2+} \text { conce }\end{array}$ & $\begin{array}{l}\text { ald \& Clark } \\
\text { tration of }\end{array}$ & $\begin{array}{l}5 \text { was based on that } \\
\mathrm{g} \mathrm{L}^{-1} \text { and } 3 \mathrm{~g} \mathrm{~L}^{-1} \text {, res }\end{array}$ & $\begin{array}{l}\text { roposed by } \\
\text { ectively. }\end{array}$ & Iverman \& Lundgren ${ }^{30} \mathrm{e}$ & cept for the \\
\hline
\end{tabular}


The ferrous ion oxidation rate was higher in those samples with higher ferrous ion concentration, probably due to the fact that increasing amounts of $\mathrm{Fe}^{2+}$ resulted in greater densities of cells that are able to transform more $\mathrm{Fe}^{2+}$ ions into $\mathrm{Fe}^{3+9}$. The linearity between initial ferrous ion concentration and its oxidation rate found in this study is not fully supported in the literature. Thus, Danis et al. ${ }^{31}$ observed that increasing $\mathrm{Fe}^{2+}$ concentrations up to $2.6 \mathrm{~g} \mathrm{~L}^{-1}$ gave increased $\mathrm{Fe}^{3+}$ levels, but higher ones led to lower $\mathrm{Fe}^{3+}$ concentrations. Karamanev and Nikolov ${ }^{32}$ showed that the $A$. ferrooxidans oxidation rate was almost unaffected by ferrous ion concentration from $4 \mathrm{~g} \mathrm{~L}^{-1}$ upwards.

The stagnation or even decrease of the ferrous ion oxidation rate is related to the inhibition suffered by A. ferrooxidans ${ }^{31,32}$. This fact was evident in our study, since both the specific bacterial growth rate and specific substrate consumption decreased at the highest ferrous ion concentration $\left(9 \mathrm{~g} \mathrm{Fe}^{2+} \mathrm{L}^{-1}\right)$. Similarly, Barron and Lueking ${ }^{23}$ observed that medium $\mathrm{Fe}^{2+}$ concentrations $\left(2-3 \mathrm{~g} \mathrm{~L}^{-1}\right)$ favoured rapid cell growth rates at low cell densities, whereas higher $\mathrm{Fe}^{2+}$ concentrations $\left(>4 \mathrm{~g} \mathrm{~L}^{-1}\right)$ should be selected to provide high cell yields but not optimum bacterial growth rates. In our study, the maximum growth rate $\left(0.17 \mathrm{~h}^{-1}\right)$ and substrate consumption ( $\left.0.009 \mathrm{mg} \mathrm{Fe}^{2+} \mathrm{Mcell}^{-1} \mathrm{~h}^{-1}\right)$ were slightly higher than those found by other authors, although it should be noted that different strains and nutrient media were employed in those reports ${ }^{23-27}$.

Consequently, the optimal conditions were found to be $\mathrm{pH} 1.5$ and a ferrous ion concentration of $6 \mathrm{~g} \mathrm{~L}^{-1}$, which ensured the highest bacterial growth rate, with moderate acid consumption and limited possibility of jarosite formation.

\section{S. thermosulfidooxidans}

Bioleaching of copper using mesophilic iron-oxidising acidophilic bacteria, such as A. ferrooxidans, which develop relatively high redox potentials during leaching processes by maintaining high ferric to ferrous ion ratios, has been extensively studied. However, the use of moderately thermophilic bacteria could be beneficial to boost bioleaching processes since higher temperatures improve both bacterial leaching kinetics and metal dissolution ${ }^{33}$. Cruz et al. ${ }^{33}$ observed that greater and faster nickel extraction was achieved from nickel sulfide ores when using $S$. thermosulfidooxidans in comparison with $A$. ferrooxidans, mainly due to the temperature effect and the rapid increase in solution redox potential. In addition, $S$. thermosulfidooxidans has been reported to be tolerant to copper ions during ferrous ion biooxidation, and its cell-growth inhibition has been established at $22 \mathrm{~g} \mathrm{~L}^{-114}$. 


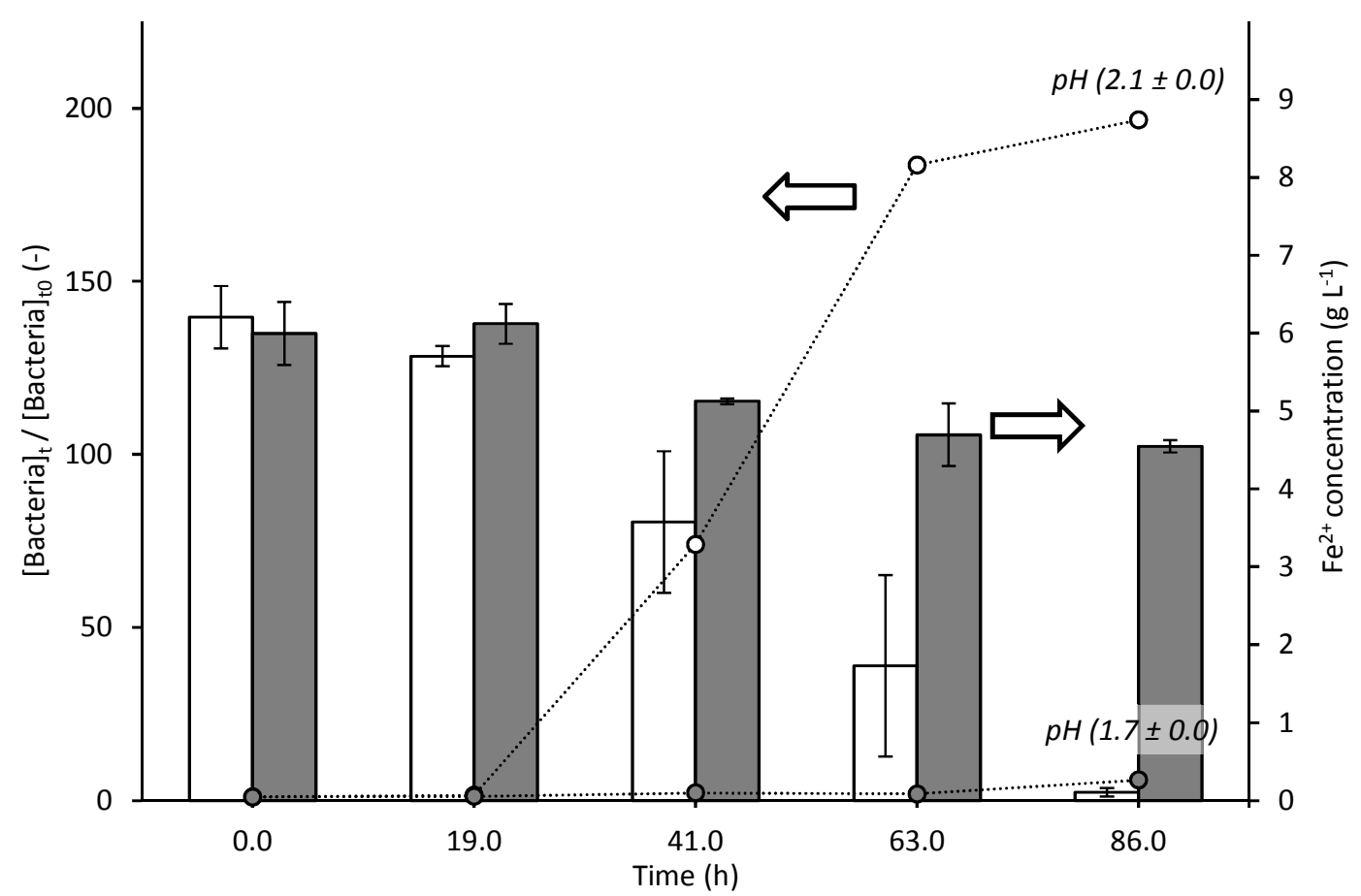

Figure 3. Evolution of $\mathrm{Fe}^{2+}$ (columns) and bacterial (circles) concentration during the culture of $S$. thermosulfidooxidans in MAC medium with an initial $\mathrm{pH}$ of 1.5 and Fe $\mathrm{F}^{2+}$ concentration of $6 \mathrm{~g} \mathrm{~L}^{-1}$ with yeast extract (white) and without supplements (grey). Error bars represent one standard deviation of the duplicates.

In this study, only the sample supplemented with yeast extract was able to complete $\mathrm{Fe}^{2+}$ oxidation. Thus, S. thermosulfidooxidans acted as a relatively poor ferrous ion oxidiser when grown in pure culture (Figure 3). This is in accordance with Pina et al. ${ }^{29}$, who highlighted the benefits of mixotrophic conditions at the expense of autotrophic ones (Table 2). S. thermosulfidooxidans showed slower growth kinetics $(\mu$ $\left.=0.11 \mathrm{~h}^{-1}\right)$ and lower ferrous ion oxidation rates $\left(\mathrm{v}_{\mathrm{Fe}^{2+}}=0.12 \mathrm{~g} \mathrm{Fe}^{2+} \mathrm{L}^{-1} \mathrm{~h}^{-1}\right)$ than $A$. ferrooxidans under the same conditions. In light of the results obtained, and setting aside the benefits owing to the higher temperatures applied (which also involves the handicap of an additional energy consumption), no potential benefit for the process can be expected in this case when using $S$. thermosulfidooxidans instead of $A$. ferrooxidans.

\section{Biomachining experiments}

Proteobacteria of the genus Acidithiobacillus, and more specifically A. ferrooxidans or A. thiooxidans, are the most widely studied bacteria in copper biomachining ${ }^{8,16}$, although reports involving bacteria of the genus Staphylococcus sp. and a strain of Aspergillus niger fungi have been published recently ${ }^{34,35}$. However, to the best of our knowledge, little information regarding the ability of moderately thermophilic bacteria in this field is available. In this section, the performance of mesophilic ( $A$. ferrooxidans) and thermophilic bacteria (S. thermosulfidooxidans) in MAC medium during copper biomachining process is compared (Figure 4). A progressive decrease in the amount of copper removed per unit time was observed for both bacteria after the maximum value had been reached during the first hour, with a maximum MRR of 109 and $117 \mathrm{mg} \mathrm{h}^{-1}$ being reached for A. ferrooxidans and $S$. thermosulfidooxidans, respectively. These values are in accordance with those obtained by Jadhav et al. ${ }^{36}$, who used $A$. ferrooxidans 13823 culture supernatant in $9 \mathrm{~K}$ medium and also observed a sustained decrease after the first hour ( $25-30 \%$ and $40-45 \%$ decrease after 2 and $3 \mathrm{~h}$, respectively). 


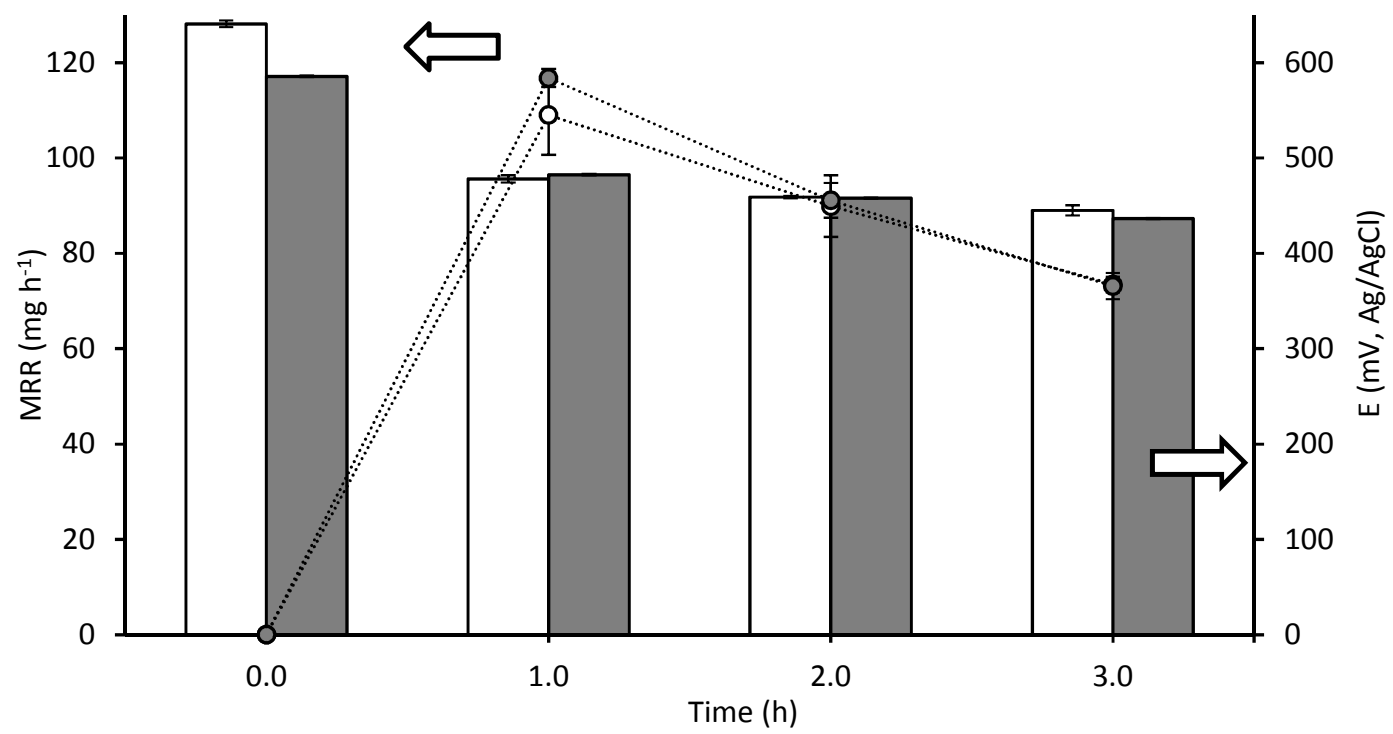

Figure 4. Evolution of redox potential (columns) and metal removal rate (circles) for A. ferrooxidans (white) and S. thermosulfidooxidans (grey) in MAC medium with an initial $\mathrm{pH}$ of 1.5 and $\mathrm{Fe}^{2+}$ concentration of $6 \mathrm{~g} \mathrm{~L}^{-1}$ (with yeast extract supplementation for the thermophilic bacteria). Error bars represent one standard deviation of the duplicates.

As stated above, the decrease in metal leaching rate with $\mathrm{Fe}^{3+}$ concentration has prevented biomachining from being implemented industrially. To address this problem, previous studies published by us $^{4}$ proposed the use of a multi-module carousel in which each module contains a ferric ion solution and a microbial consortium that is able to oxidize $\mathrm{Fe}^{2+}$ ions. The workpiece remains submerged in each solution as long as the MRR is a maximum. During that period, acidophilic bacteria (i.e., A. ferroxidans) regenerate the ferric ion concentration in the rest of the modules. The novelty of this study lies in the achievement of a stable, controlled and continuous biomaching process by means of a unique dissolution tank in which bacterial culture and biomachining take place at the same time ("Biomachining during culture period" section). In this case, continuous bacterial growth at its maximum degrading activity would be accomplished since the higher kinetics of the chemical reaction would ensure the availability of the substrate ( $\mathrm{Fe}^{2+}$ ions) (Figure 1c). The key is therefore to overcome the difference between chemical and microbiological reaction rates to achieve a good balance and the desired MRR stability.

\section{Biomachining during culture}

A copper bioleaching process in which bacterial growth and workpiece biomachining take place at the same time has been envisaged in this section. Jarosite accumulation was visually observed in those samples with no $\mathrm{pH}$ control after $38 \mathrm{~h}\left(\mathrm{pH}_{\text {final }} 2.3\right)$ and $86 \mathrm{~h}\left(\mathrm{pH}_{\text {final }} 2.5\right)$ for A. ferrooxidans and $S$. thermosulfidooxidans, respectively, thereby reducing iron availability in the solution (precipitation above $60 \%$ of total iron) and concluding the process prematurely. 
In those experiments with $\mathrm{pH}$ control, $S$. thermosulfidooxidans showed a seven-times lower MRR in comparison with $A$. ferrooxidans after operation for 1 day $\left(1.72 \mathrm{vs} 12.6 \mathrm{mg} \mathrm{h}^{-1}\right)$. In addition, growth of $S$. thermosulfidooxidans was limited in comparison with its performance during standard culture (SI Figure S5), which might be related to its low toleration to copper cations, thereby significantly reducing previous inhibition limits reported in the literature for different strains of the same species ${ }^{14}$. Similarly, Watking et al. ${ }^{37}$ previously observed that metal tolerance ( $\mathrm{Fe}, \mathrm{Cu}, \mathrm{Zn}, \mathrm{Ni}$ and $\mathrm{Co}$ ) varied significantly between strains of the same specie. Regarding $A$. ferrooxidans cell density, bacteria seemed to grow faster when biomachining was performed together with the growth step (SI Figure S6). In addition, the bacteria developed in the latter experiments reached a smaller size, which could be related to the increase in ferrous-oxidizing activity ${ }^{38}$.

The biomachining test using $A$. ferrooxidans showed an increase in MRR $\left(\sim 43 \mathrm{mg} \mathrm{h}^{-1}\right)$ for the first 50 hours (Figure 5), subsequently remaining constant over the following $30 \mathrm{~h}$. Although a stable copper removal rate over time was achieved, the maximum MRR reached was less than half the value attained during conventional biomachining $\left(109 \mathrm{mg} \mathrm{h}^{-1}\right.$ ) (Figure 4). Moreover, the copper removal rate remained constant even though the amount of $\mathrm{Fe}^{3+}$ available also increased throughout the experiment. Jarosite formation was discarded as a cause of this stagnation since the total iron content in the medium remained approximately constant throughout the test $\left(\sim 6 \mathrm{~g} \mathrm{~L}^{-1}\right)$. One possible explanation might be related to biofouling as a result of the adhesion of microorganisms and subsequent biofilm formation on the workpiece surface ${ }^{39}$. The resulting passivating layer would prevent ferric ion migration, thus inhibiting the biomachining process ${ }^{40}$.
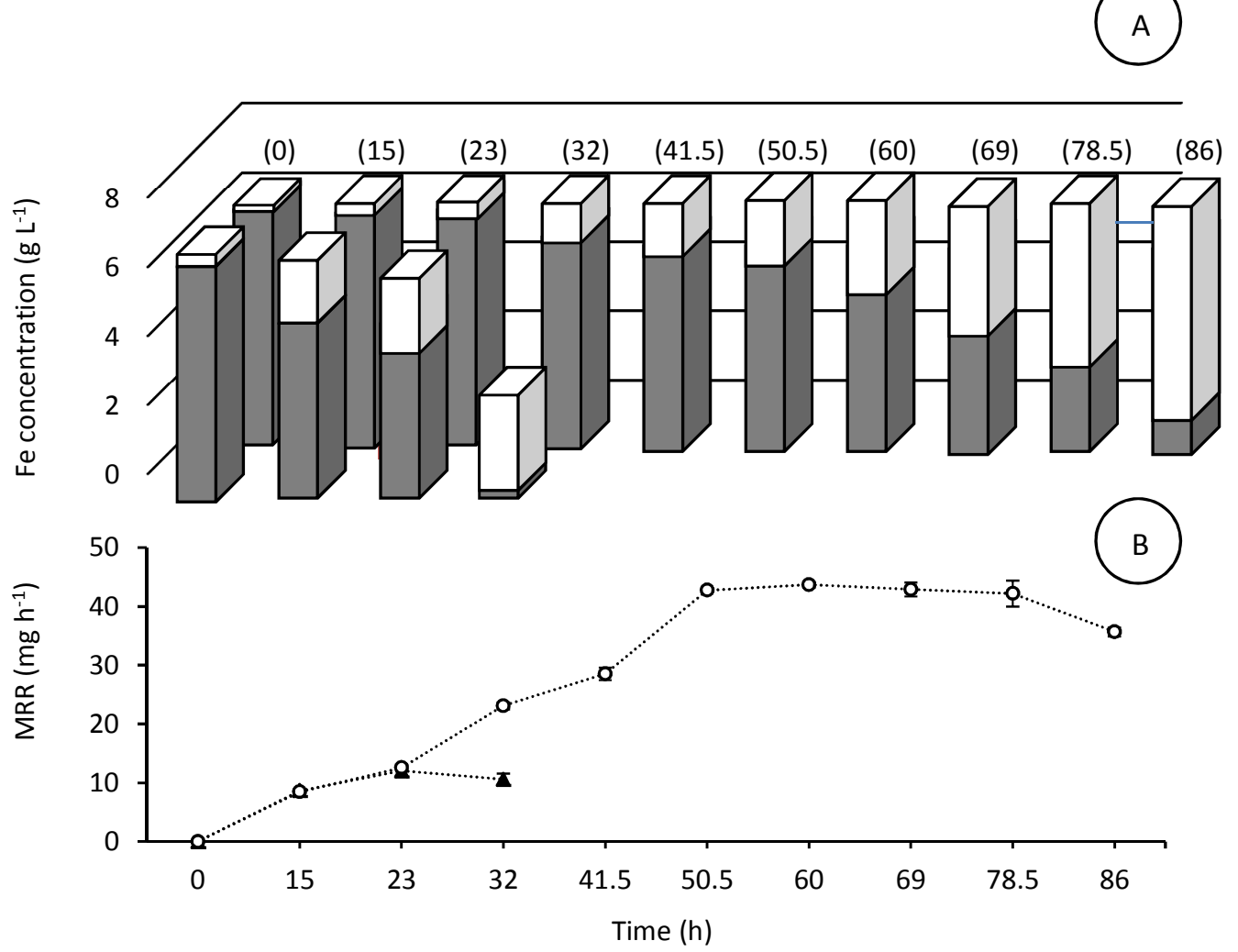

Figure 5. Evolution of $\mathrm{Fe}^{2+}$ (grey columns) and $\mathrm{Fe}^{3+}$ (white columns) concentration during simultaneous bacterial culture and biomachining for $A$. ferrooxidans in $\mathrm{MAC}$ medium (initial $\mathrm{pH} 1.5$ and $\mathrm{Fe}^{2+}$ concentration of $6 \mathrm{~g} \mathrm{~L}^{-1}$ ) with no $\mathrm{pH}$ control (front row) and with a constant $\mathrm{pH}$ threshold value of 1.8 (back row) (A); metal removal rate observed in these experiments (with no $\mathrm{pH}$ control (black triangles) and for a maximum $\mathrm{pH}$ of 1.8 (white circles)) (B). 


\section{SUMMARY}

Despite the potential benefits of biomachining (e.g., environmentally friendly nature) as an alternative to conventional chemical and physical manufacturing processes, its industrial application has not yet been completed. However, more in-depth studies of the chemical and biological aspects of this process, as well as the influence of the most significant process parameters, could promote its industrial implementation. In this case, the use of extremophile mesophilic (A. ferrooxidans) and thermophilic (S. thermosulfidooxidans) bacteria to remove copper from OFC workpieces has been investigated. Unlike the obligate chemolithoautotroph A. ferrooxidans, S. thermosulfidooxidans only exhibited measurable growth rates in mixotrophic conditions, therefore its nutrient medium had to be supplemented with yeast extract. Despite this, A. ferrooxidans showed a higher specific bacterial growth rate and specific substrate consumption under the optimal conditions (initial pH and Fe ${ }^{2+}$ concentration of 1.5 and $6 \mathrm{~g} \mathrm{~L}^{-1}$ and $30{ }^{\circ} \mathrm{C}$ (for A. ferrooxidans) or $45{ }^{\circ} \mathrm{C}$ (for S. thermosulfidooxidans)) in MAC medium. Jarosite formation and precipitation was observed when the $\mathrm{pH}$ exceeded the value of 2.2 for samples with a total iron content $\geq 6 \mathrm{~g} \mathrm{~L}^{-1}$.

As expected, when the A. ferrooxidans growth (cultivation period) and machining stages were performed simultaneously, a stable copper removal rate in the range $40-45 \mathrm{mg} \mathrm{h}^{-1}$ was obtained. This method avoided $\mathrm{Fe}^{3+}$ depletion in the medium, which is the key factor governing the machining rate. In contrast, the maximum MRR achieved was less than half of the value attained during conventional biomachining with $\mathrm{pH}$ adjustment $\left(109 \mathrm{mg} \mathrm{h}^{-1}\right)$. A linear $\mathrm{Fe}^{3+}$ concentration increase in the medium (51 $\left.\mathrm{mg} \mathrm{h}^{-1}, \mathrm{R}^{2}=0.951\right)$ ) from the hour 20 onwards suggested a decrease in cation diffusion, probably caused by the attachment of microorganisms to the metallic surface, thus acting as a weak diffusion barrier.

\section{SUPPORTING INFORMATION}

Image of an OFC workpiece placed within a conical flask together with the uncultured inoculum in MAC medium during simultaneous bacterial growth and copper machining test, jarosite precipitation in samples with an initial $\mathrm{pH}$ of 2.0 and $\mathrm{Fe}^{2+}$ concentration of $6 \mathrm{~g} / \mathrm{L}$ and $9 \mathrm{~g} / \mathrm{L}$, DAPI-stained microscopy images of $A$. ferrooxidans and $S$. thermosulfidooxidans grown with and without the presence of copper OFC samples within the flasks and the correlation between ferrous iron concentration depletion and redox potential increase during $A$. ferroxidans culture period.

\section{ACKNOWLEDGEMENTS}

The authors wish to acknowledge the financial support received from the State Agency for Research (AEI) of the Spanish Government and the European Regional Development Fund (ERDF) (Project CTM2016-77212-P) and from the University of the Basque Country UPV/EHU (GIU 15/20 and PIC 09/18). The CINDEFI is also acknowledged for their technical support.

\section{REFERENCES}

(1) International Copper Study Group (ICSG), 2016. The world copper factbook 2014. Available at: (http://copperalliance.org/wordpress/wp-content/uploads/2012/01/ICSG-Factbook-2014.pdf).

(2) Glöser, S.; Soulier, M.; Tercero Espinoza, L.A. Dynamic analysis of global copper flows. global stocks, postconsumer material flows, recycling indicators, and uncertainty evaluation. Environ. Sci. Technol. 2013, 47, 6564-6572.

(3) Pusavec, F.; Krajnik, P.; Kopac, J. Transitioning to sustainable production - Part I: application on machining technologies. J. Cleaner Prod. 2010, 18, 174-184. 
(4) Díaz-Tena, E.; Gallastegui, G.; Hipperdinger, M.; Donati, E.R.; Ramírez, M.; Rodríguez, A.; López de Lacalle, L.N.; Elías, A. New advances in copper biomachining by iron-oxidizing bacteria. Corros. Sci. 2016, 112, 385-392.

(5) Díaz-Tena, E.; Barona, A.; Gallastegui, G.; Rodríguez, A.; Norberto López de Lacalle, L.N.; Elías, A. Biomachining: metal etching via microorganisms. Crit. Rev. Biotechnol. 2017, 37, 323-332.

(6) Hocheng, H.; Jadhav, U.U.; Chang, J.H. Biomachining rates of various metals by Acidithiobacillus thiooxidans. Int. J. Surf. Sci. Eng. 2012, 6, 101-111.

(7) Tributsch, H. Direct versus indirect bioleaching. Hydrometallurgy. 2001, 59, 177-185.

(8) Xenofontos, E.; Feidiou, A.; Constantinou, M.; Constantinides, G.; Vyrides, I. Copper biomachining mechanisms using the newly isolated Acidithiobacillus ferrooxidans B1. Corros. Sci. 2015, $100,642-650$.

(9) Muhammad, I.; Ullah, S.M.S; Han, D.S.; Jo, T. Selection of optimum process parameters of biomachining for maximum metal removal rate. Int. J. Precis Eng Manuf-Green Technol. 2015, 2, 307313.

(10) Lambert, F.; Gaydardzhhiev, S.; Léonard, G.; Lewis, G.; Bareel, P.F.; Bastin, D. Copper leaching from waste electric cables by biohydrometallurgy. Miner. Eng. 2015, 76, 38-46.

(11) University of the Basque Country. ES2594013. 2017-09-20. Available at: (https://worldwide.espacenet.com/publicationDetails/originalDocument?FT=D\&date=20170920\&DB=E PODOC\&locale $=$ en $E P \& C C=E S \& N R=2594013 B 1 \& K C=B 1 \& N D=4$ )

(12) Mackintosh, M.E. Nitrogen fixation by Thiobacillus ferrooxidans. J. Gen. Microbiol. 1978, $105,215-218$.

(13) Gomez, J.M.; Cantero, D. Ferrous sulphate oxidation by Thiobacillus ferrooxidans in discontinuous culture: influence of temperature, $\mathrm{pH}$ and agitation rate. J. Ferment. Bioeng. 1998, 86, 79-83.

(14) Watling, H.R.; Perrot. F.A.; Shiers, D.W. Comparison of selected characteristics of Sulfobacillus species and review of their occurrence in acidic and bioleaching environments. Hidrometallurgy. 2008, 93, 57-65.

(15) Yang, Y.; Wang, X.; Liu, Y.; Wang, S.; Wen, W. Techniques for micromachining using Thiobacillus ferrooxidans based on different culture medium. Appl. Mech. Mater. 2009, 16-19, 10531057.

(16) Chang, J.H.; Hocheng, H.; Chang, H.Y.; Shih, A. Metal removal rate of Thiobacillus thiooxidans without pre-secreted metabolite. J. Mater. Process. Technol. 2008, 201, 560-564.

(17) Kolthoff, I.M.; Sandell, E.B.; Meehan, E.J.; Bruckenstein, S., Eds. Análisis Químico Cuantitativo ( $6^{\text {th }}$ Edition); Editorial Nigar: Buenos Aires, Argentina, 1998.

(18) Urbieta, M.S.; González, E.; Giaveno, M.A.; Aguilera, A.; Donati, E.R. Archeal and bacterial diverstiy in five different hydrothermal ponds in the Copahue region in Argentina. Syst. Appl. Microbiol. 2014, 37, 429-441.

(19) Nazari, B.; Jorjani, E.; Hani, H.; Manafi, Z.; Riahi, A. Formation of jarosite and its effect on important ions for Acidithiobacillus ferrooxidans bacteria. Trans. Nonferrous Met. Soc. China. 2014, 24, 1152-1160.

(20) Blanch, H.W., Clark, D.S., Eds. Biochemical engineering. Marcel Dekker, INC: New York, 1996. 
(21) Deveci, H.; Akcil, A.; Alp, I. Parameters for control and optimisation of bioleaching of sulphide minerals. In: Process Control and Optimization in Ferrous and Non Ferrous Industry, Materials Science and Technology 2003 Symposium; Kongoli, F., Thomas, B., Sawamiphakdi, K. (Eds.); TMS, Warrendale, PA, pp. 77-90, 2003.

(22) Liang, G.; Li, P.; Liu, W.; Wang, B. Enhanced bioleaching efficiency of copper from waste printed circuit boards (PCBs) by dissolved oxygen-shifted strategy in Acidithiobacillus ferrooxidans. J. Mater. Cycles Waste Manage. 2016, 18, 742-751.

(23) Barron, J.L.; Lueking, D.R. Growth and maintenance of Thiobacillus ferrooxidans cells. Appl. Environ. Microbiol. 1990, 56, 2801-2806.

(24) Gomez, J.M.; Cantero, D. Modelling of ferrous sulphate oxidation by Thiobacillus ferrooxidans in discontinuous culture: Influence of temperature, $\mathrm{pH}$ and agitation rate. J. Ferment. Bioeng. 1998, 86, 79-83.

(25) MacDonald, D.G.; Clark, R.H. The oxidation aqueous ferrous sulphate by Thiobacillus ferrooxidans. Can. J. Chem. Eng. 1970, 47, 669-676.

(26) Jaisankar, S.; Modak, J.M. Ferrous ion oxidation by foam immobilized Acidithiobacillus ferrooxidans: experiments and modelling. Biotechnol. Prog. 2009, 25, 1328-1342.

(27) Kumar, S.R.; Gandhi, K.S. Modelling of $\mathrm{Fe}^{2+}$ oxidation by Thiobacillus ferrooxidans. Appl Microbiol. Biotechnol. 1990, 33, 524-528.

(28) Veloso, T.C.; Sicupira, L.C.; Rodrigues, I.C.B.; Silva, L.A.M.; Leao, V.A. The effects of fluoride and aluminium ions on ferrous ion oxidation and copper sulphide bioleaching with Sulfobacillus thermosulfidooxidans. Biochem. Eng. J. 2012, 62, 48-55.

(29) Pina, P.S.; Oliveira, V.A.; Cruz, F.L.S.; Leão, V.A. Kinetics of ferrous ion oxidation by Sulfobacillus thermosulfidooxidans. Biochem. Eng. J. 2010, 51, 194-197.

(30) Silverman, M.P.; Lundgren, D.G. Studies on the chemoautotrophic iron bacterium Ferrobacillus ferrooxidans. An improved medium and a harvesting procedure for securing high cell yields. J. Bacteriol. 1959, 77, 642-647.

(31) Danis, U.; Nuhoglu, A.; Demirbas, A.; Ferrous ion-oxidizing in Thiobacillus ferrooxidans batch cultures: influence of $\mathrm{pH}$, temperature and initial concentration of $\mathrm{Fe} 2+$. Fresenius Environ. Bull. $2008,17,371-377$.

(32) Karamanev, D.G.; Nikolov, L.N. Influence of some physicochemical parameters on bacterial activity of biofilm: ferrous ion oxidation by Thiobacillus ferrooxidans. Biotechnol. Bioeng. 1988, 31, 295299.

(33) Cruz, F.L.S.; Oliveira, V.A.; Guimaraes, D.; Souza, A.D.; Leao, V.A. High-temperature bioleaching of nickel sulfides: thermodynamic and kinetic implications. Hydrometallurgy. 2010, 105, 103-109.

(34) Shikata, S.; Sreekumari, K.R.; Nandakumar, K.; Ozawa, M.; Kikuchi, Y. Laboratory studies on biomachining of copper using Staphylococcus sp. Biofouling. 2009, 25, 557-562.

(35) Jadhav, U.; Hocheng, H. Use of Aspergillus niger 34770 culture supernatant for tin metal removal. Corros. Sci. 2014, 82, 248-254. 
(36) Jadhav, U.; Hocheng, H.; Weng, W. Innovative use of biologically produced ferric sulfate for machining of copper metal and study of specific metal removal rate and surface roughness during the process. J. Mater. Process. Technol. 2013, 213, 1509-1515.

(37) Watkin, E.L.J.; Keeling, S.E.; Perrot, F.A.; Shiers, D.W.,; Palmer, M.L.; Watling, H.R. Metals tolerance in moderately thermophilic isolates from a spent copper sulfide heap, closely related to Acidithiobacillus caldus, Acidimicrobium ferrooxidans and Sulfobacillus thermosulfidooxidans. J. Ind. Microbiol. Biotechnnol. 2008, 36, 461-465.

(38) Groudev, S. Leaching of copper-bearing mineral substrates with wild microflora and with laboratory-bred strains of Thiobacillus Ferrooxidans. In: Biogeochemistry of Ancient and Modern Environments; Trudinger, P.A., Walter, M.R., Ralph, B.J. (Eds); Springer, Berlin, Heidelberg, 1980.

(39) Cwalina, B.; Dec, W.; Michalska, J.K.; Jaworska-Kik, M.; Student, S. Initial stage of the biofilm formation on the NiTi and Ti6Al4V surface by the sulphur-oxidizing bacteria and sulphatereducing bacteria. J. Mater. Sci. - Mater. Med. 2017, DOI 10.1007/s10856-017-5988-2.

(40) Yu, R.L.; Zhong, D.L.; Miao, L.; Wu, F.D.; Qiu, G.Z.; Gu, G.H. Relationship and effect of redox potential, jarosites and extracellular polymeric substances in bioleaching chalcopyrite by acidithiobacillus ferrooxidans. Trans. Nonferrous Met. Soc. China. 2011, 21, 1634-1640. 


\section{SYNOPSIS}

Simultaneous bacterial growth and copper machining in oxygen-free copper workpieces enables a constant metal removal rate by extremophile bacteria.

ABSTRACT GRAPHIC (for table of contents use only)

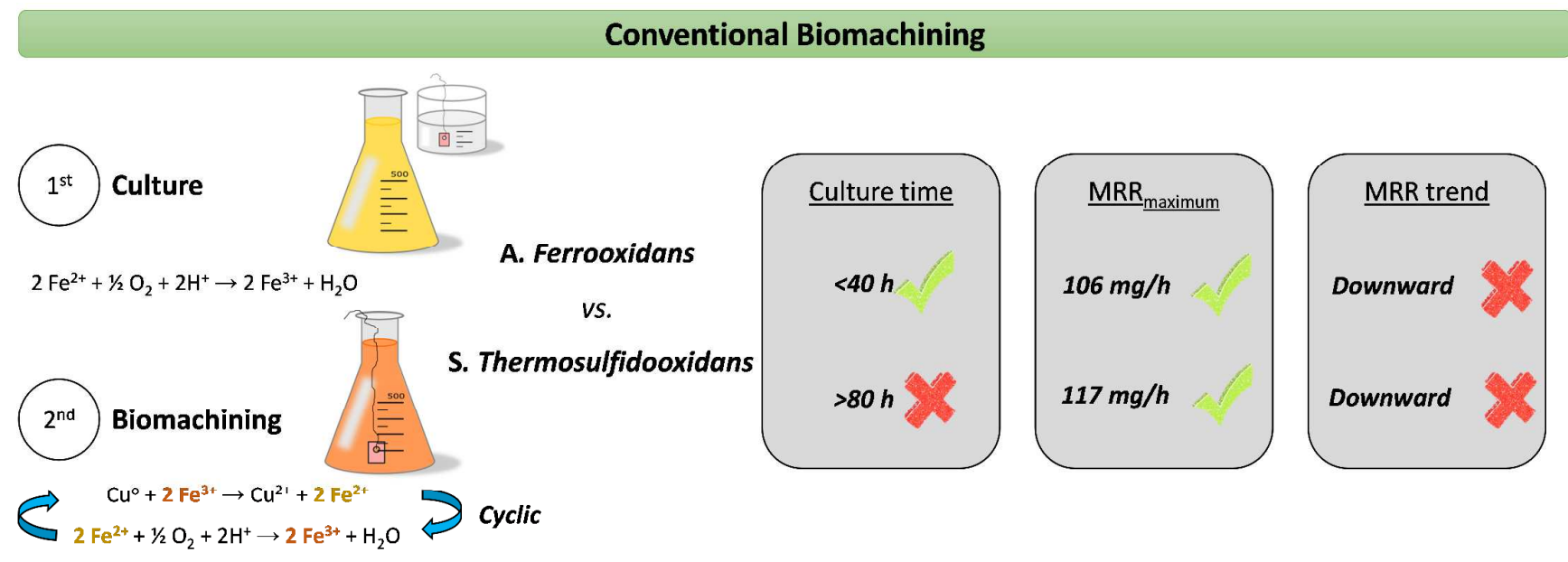

Simultaneous bacterial growth + biomachining
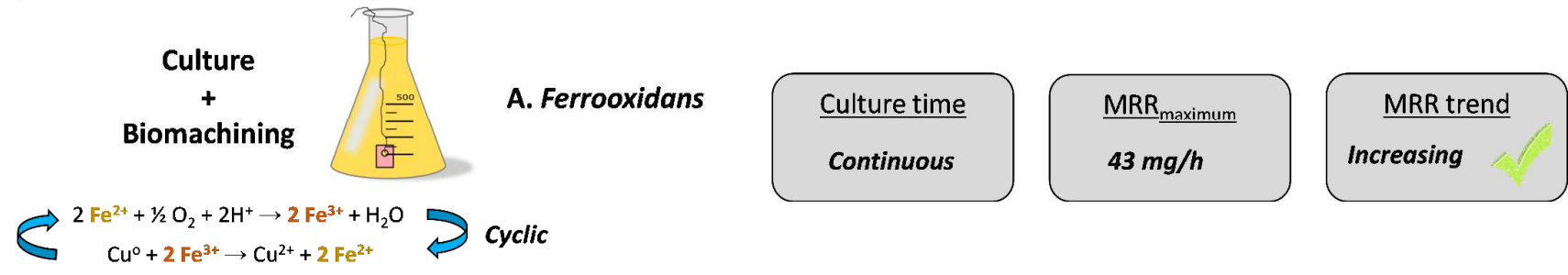